\title{
EFFECT OF SMOKING ON SURVIVAL AMONG HIV/AIDS PATIENTS IN KEDU, CENTRAL JAVA
}

\author{
Tuti Susilowati1), Tri Nur Kristina2), Muclis Au Sofro3) \\ 1)Doctoral Program, Universitas Diponegoro \\ 2)Faculty of Medicine, Universitas Diponegoro \\ 3) Dr. Karyadi Hospital, Semarang \\ 4)School of Health Science Muhammadiyah, Klaten
}

\begin{abstract}
Background: Human Immuno-Deficiency Virus (HIV) continues to be a major global public health issue. In 2016, an estimated 36.7 million people were living with HIV (including 1.8 million children) - with a global HIV prevalence of $0.8 \%$ among adults. Despite the recent declines in global HIV/AIDS mortality, today, HIV/AIDS remains one of the leading global causes of both mortality and burden. This study aimed to estimate the effect of smoking on survival among HIV/AIDS patients in Kedu, Central Java.

Subjects and Methods: This was a cohort study conducted at Kedu, Central Java. A sample of 152 HIV patients was selected for this study. The dependent variable was death. The independent variable was smoking. HIV data were taken from medical record. The other data were collected by questionnaire. The data were analyzed by a Cox Proportional Hazard Model. Results: Mean age of the sample was 33 years, $69.7 \%$ were male, $53.3 \%$ had high education, $69.8 \%$ were smoker, and $10.5 \%$ died. The risk of mortality increased with smoking ( $\mathrm{HR}=2.82$; $95 \% \mathrm{CI}=1.05$ to 7.56$)$.
\end{abstract}

Conclusion: Smoking increases the risk of dying among patients of HIV/ AIDS.

Keywords: HIV/AIDS, smokers, survival

\section{Correspondence:}

Tuti Susilowati. Doktoral Program, Universitas Diponegoro, Semarang, Central Java. Email: iyya_salaman@yahoo.co.id. Mobile: +6281357337149. 